\title{
First Person Account of Returning to Education and Competitive Employment Following Serious Mental Illness
}

\author{
Matthew Pommeranz $\cdot$ Jeffrey Lawrence $\cdot$ Frances Dark
}

Received: 8 June 2021 / Accepted: 28 June 2021

(C) The Author(s) 2021

\begin{abstract}
Education and work goals are important for people with serious mental illness. For many these goals remain unmet. Increasingly people with serious mental illness are inspired by the stories of people who have been able to meet the challenges of gaining education and stable employment. Two peer workers describe their personal journeys to stable employment. Both authors note the significance of having someone believe in their potential to work. The benefits of stable employment went beyond finances and included improved self-esteem and an altruistic wish to provide a role model for others recovering from mental illness.Functional recovery from serious mental illness (SMI) especially in terms of completed education and employment goals is suboptimal. The clinical evidence base in enhancing functional recovery is increasingly complemented by the growing evidence
\end{abstract}

Matthew Pommeranz and Jeffrey Lawrence have contributed equally.

M. Pommeranz $\cdot$ J. Lawrence

Metro South Addiction and Mental Health Services,

PO Box 585, Cleveland, Queensland 4163, Australia

e-mail: Matthew.Pommeranz@health.qld.gov.au

J. Lawrence

e-mail: Jeffrey.Lawrence@ health.qld.gov.au

F. Dark $(\bowtie)$

Metro South Addiction and Mental Health Services, 228

Ipswich Rd, Woolloongabba, Australia

e-mail: Frances.dark@health.qld.gov.au base developed by the consumer network and by the rise in prominence of peer workers as a significant adjunctive mental health workforce.

Keywords Peer worker $\cdot$ Education $\cdot$ Work $\cdot$ Serious mental illness $\cdot$ Recovery

\begin{abstract}
Aim
This paper aims to leverage the power of first-person accounts to inspire hope that educational and work goals are obtainable despite the reality of severe mental illness.
\end{abstract}

\section{Method}

Two peer workers describe their journey to ongoing education and achieving stable competitive work.

\section{Results}

$\operatorname{Mr} \mathrm{A}$

Leaving school, I had a family member put in a good word at a local data cabling company. This job lasted a year before I found an electrical apprenticeship. I had good grades and performed at my job working night 
shift under short deadlines. I had only just finished my electrical apprenticeship when I was made redundant.

I fell ill a few months afterwards. Following my diagnosis, I was barely functional and even just showering or going for a walk was important. Work was not a priority, and I did not even think of returning to work for a few years. I had always thought of going back to doing electrical work and did not think about a change of career. Coming to the residential rehabilitation unit (RRU) opened new opportunities and gave me a new lease on life. It was re-invigorating and the shakeup I needed after living with my parents for years whilst unwell.

Following my rehabilitation at the RRU I started running a hearing voices group at a local nongovernment organisation (NGO). I got my confidence back and it gave me a foot in the door to working as a peer worker. I managed a role on the board of management. This in turn opened other opportunities and I ended up doing a placement as a peer worker. This was invaluable experience and helped with completing further training in both Peer Work and Mental Health.

Being a group facilitator for an NGO was a huge boost and enabled me to get a feel for peer work. Starting off volunteering facilitating a hearing voices group and then slowly increasing to 3 days a week enabled me to test the waters and see if I could cope. I also received great training such as Applied Suicide Intervention Skills Training, Peer Zone, Emotional $\mathrm{CPR}$, and various other helpful courses/experiences. Facilitating groups is a passion and I feel like a confident and competent facilitator.

Seeing the impact, a peer can make both at the RRU and in the wider community made me think of a career change. The peer workers role model recovery and this gave me hope in my own recovery. I was told constantly by peers and peer workers I would make a great peer worker one day. This gave me confidence to try something different. Going from a trade to something more meaningful felt right but it also felt like it was a natural pathway in my recovery. It seemed like I could make a difference to someone's life but also enhance my own life at the same time.

I have only been in the Peer worker role at RRU for just over a year, but I have settled in with the team and residents. I am growing in the role as a peer worker. Moving from a focus on group work to individual support has been a little challenging but I have learnt a lot and am keen to further my toolkit for dealing with people one on one and in crisis. It is a significant role and I always look forward to a shift, I value going to work and being part of a team.

Sometime in the future I would like to do either a Diploma of Community Services or an Enrolled Mental Health Nurse. In the meantime, I am happy to climb the peer ladder and look forward to furthering my career as a peer worker and aim for a senior position when the opportunity presents itself.

In my opinion the barriers to returning to education and work following the experience of developing a mental illness and the journey to recovery, involve learning to live again whilst being unwell or learning to live with a diagnosis is huge. The simplest of tasks can seem unreachable.

\section{Mr B}

School was a very disenchanting journey for me. The environment was not very inspiring due to abuse that had occurred throughout my school years. My plans for work were either to play basketball professionally at some level or join the army. I believed with some confidence that this was the right path for me, however there were always doubts about how meaningful this was for me or what I would achieve in life.

My diagnosis seemed very bleak with little positive outlook for the future. I did not plan to do much else except what I was already doing which was substance misuse and alcoholism. I did study smaller certificates for some time and was enrolled in a horticulture/ permaculture certificate however never completed them. My early years in education left me with a sour taste in my mouth so I was always pessimistic about my education in general.

Before I came to the RRU I was encouraged by my previous Mental Health (MH) team to study the certificate in Peer work. My previous team had inspired a lot of hope in me about my future in peer work and I was very encouraged by peer workers and the staff around them that had been working with me throughout my treatment.

I choose this career because I wanted to inspire hope in others the way the peer workers and staff in my treatment inspired me in my darkest times. My team believed in me and that in turn helped me believe in myself. I could see a future for myself beyond the revolving door of substance misuse and $\mathrm{MH}$ inpatient 
treatment. I would like to pay it forward to help the people of whom I am involved in their care. Peer work has also helped me with my self-esteem and the altruistic nature of contributing to people achieving their goals and living a fulfilling life.

My journey to becoming a MH peer worker begins in childhood. At an early age and through my years in school I was witness to or victim of abuse at the hands of authority figures in institutions. In turn this led me to be a very cynical adolescent and early adult. My substance abuse in those years was a direct result and reaction to the trauma I had experienced. After I finished school, I tried my best to cope with multiple illicit substances to self-medicate.

It was not long until I encountered $\mathrm{MH}$ services resulting from a combination of traumatic memories and substance misuse. I eventually ended up being homeless and getting into an altercation with a person I believed was sexually assaulting women. During an inpatient admission I was encouraged by a registrar to study Peer Support work. This was the spark I needed, for someone to believe in me when I could not see a future for myself.

I was transferred to an RRU. I saw firsthand how powerful peer workers could be inspiring hope and leading by example. I also attended peer support organisations which helped me gain the confidence to support others. I next transferred into private accommodation. I secured a job working as a peer support worker in alcohol and drug misuse. I now have permanent work as a peer worker at the RRU unit I had graduated from.

The barriers are often that people do not believe in themselves. They cannot visualise and see an alternative future because of the stigma of mental illness and when the prognosis can seem so bleak. If we could only show more people that it is possible to have fulfilling and meaningful life with a $\mathrm{MH}$ diagnosis. That is exactly what peer work is about.

\section{Discussion}

There can be environmental, structural, and interpersonal barriers to achieving educational and work goals while living with a serious mental illness [1]. Peer role models demonstrate to individuals negotiating this path but also to mental health services and the community that these barriers can be overcome.

Funding None

\section{Declarations}

Conflict of interest The author declare that they have no conflict of interest.

Open Access This article is licensed under a Creative Commons Attribution 4.0 International License, which permits use, sharing, adaptation, distribution and reproduction in any medium or format, as long as you give appropriate credit to the original author(s) and the source, provide a link to the Creative Commons licence, and indicate if changes were made. The images or other third party material in this article are included in the article's Creative Commons licence, unless indicated otherwise in a credit line to the material. If material is not included in the article's Creative Commons licence and your intended use is not permitted by statutory regulation or exceeds the permitted use, you will need to obtain permission directly from the copyright holder. To view a copy of this licence, visit http://creativecommons.org/licenses/by/4.0/.

\section{Reference}

1. Morgan VA et al,. People living with psychotic illness 2010: report on the second nationalmental health survey. Aust N Z J Psychiatry. 2012;46:735-52.

Publisher's Note Springer Nature remains neutral with regard to jurisdictional claims in published maps and institutional affiliations. 